\title{
Uncertain Lives: Migration, the Border and Neoliberalism in Australia
}

\author{
'We decide who comes into this country \\ and the circumstances in which they come' \\ John Howard, used in the 2001 election campaign.
}

'But to live outside the law, you must be honest' Bob Dylan ‘Absolutely Sweet Marie’.

The election in 1996 of the Liberal and National coalition government under John Howard was a tipping point in the deployment of neoliberal economic and governmental policies in Australia. However, such policies had begun to be deployed earlier, during the time of the Labor government of Bob Hawke, when Paul Keating was Treasurer. Labor, under Hawke, came to power in 1983. Keating was Treasurer from the start. In 1991 Keating became Prime Minister. This trajectory, from Hawke to Keating to Howard, marks the increasing implementation of neoliberal practices in Australia. As these practices were implemented so there was a transformation in the understanding of the Australian border. There are many markers of this transformation, starting, most obviously, with the institution of mandatory detention for asylum seekers, a practice begun by Hawke's government and formalised by Keating's. During the time of the Howard government we can also identify the Tampa affair, which I shall outline later, Operation Relex, in which the navy was used to turn back boats loaded with asylum seekers, and the establishment of detention centres beyond Australia's border, in other Pacific countries, known as the Pacific Solution, as more key moments, among others, in the border's transformation.

The mandatory detention of asylum seekers was part of a larger ideological shift associated with neoliberal policy implementation. As Australia's industrial base shrank, so neoliberal practices such as the establishment of the 457 
visa in 1996, which brought skilled labour to Australia for only as long as the people with those skills were required, became the means by which a transformation in Australia's migration intake was effected. One element in this transformation was a decreased need for unskilled, manual labour. At the same time, there was an increased need for specialised, skilled workers across a range of trade and professional areas. By 2008 the skilled component of the permanent intake in the migration program stood at 70\% (Kelly, 2008).

It is, again, no coincidence that during the 11 years of Howard's Coalition government, at the same time that large numbers of skilled temporary and longterm migrants were able to enter Australia, in 2001-02 53,520 skilled migration visas were issued rising rapidly to 97,500 in 2005-06, a furore of anxiety and anguish was whipped up over the comparatively very small number of asylum seekers. Official figures tell us that, in 1998-9, 921 asylum seekers arrived by boat. In 1999-2000 this figure increased to 4,175 and remained roughly steady in 2000-2001 at 4,141. In November 2001, around 3,400 people were being held in immigration detention facilities. We should note that, at the same time, in 20078, Australia granted 13,014 visas under the refugee resettlement program. There is, then, a stark contrast between the welcome given to the relatively high numbers of skilled migrants and the treatment apportioned to putatively unskilled asylum seekers as well as the small number of refugees permitted to enter the country. While many asylum seekers are, in fact, skilled, the image of the asylum seeker is predominantly of someone unskilled. In a study of the cultural construction of the asylum seeker conducted in the South Australian city of Port Augusta, Natascha Klocker (2008) found that $48.5 \%$ of respondents thought of asylum seekers as unskilled. Only 19.5\% of Klocker's respondents thought of asylum seekers as skilled.

In short, in terms of the market logic of neoliberalism, asylum seekers and refugees are considered too expensive to skill in the areas where it has been identified that Australia has needs. Mares (2001) reports on a presentation given by Philip Ruddock, the Minister for Immigration, in 2000. Ruddock asserted that: 
for every 1000 people who enter the country as skilled or business migrants, there is a net gain to the Commonwealth budget of \$36.7 million over five years. By contrast family migrants cost the budget $\$ 1.8$ million over the same period, while 1000 refugees and humanitarian entrants represent a much bigger burden, draining the government coffers of $\$ 21.5$ million (Mares, 2001, p.103).

In 1991-92 the Department of Immigration, Local Government and Ethnic Affairs calculated that the total cost of operating the Curtin Immigration Detention Centre was $\$ 7,922$ million. There being 294 detainees this works out at $\$ 27,184$ per person (Reilly, 1995). More recently, Chris Evans, the Labor Minister for Immigration and Citizenship has noted that, in 2006-07, it cost \$220 million to operate the immigration detention system (Vernon, 2008). There have been attempts to recoup some of this outlay. On release, unsuccessful asylum seekers are charged for the cost of their detention. In 2002:

During the last three years, according to the Immigration Department, unsuccessful asylum seekers have been charged a total of \$18 million for their detention. Some have received bills for $\$ 100,000$ or more. That doesn't include the tab for court cases and appeals, which can easily exceed \$10,000 (Paddock, 2002).

The government did not expect these bills to be paid but those with unpaid bills were unable to apply to re-enter Australia. Economic practice thus became one way of excluding unwanted migrants.

\section{Neoliberalism and Australian Politics}

In The Shock Doctrine, Naomi Klein argues that the spread of neoliberalism has been facilitated by the opportunistic use of crises to enable the imposition of its economic policies. She writes that: ‘

As I dug deeper into the history of how this market model had swept the globe ... I discovered that the idea of exploiting crisis and disaster had been the modus operandi of Milton Friedman's movement from the very beginning - this fundamentalist form of capitalism has always needed disasters to advance (Klein, 2007, p. 11). 
Often these crises are central to the system on which neoliberal policies are to be imposed. The classic example is Augusto Pinochet's coup in Chile in 1973 about which Klein has much to say.

Sometimes the crisis can occur on the edge of the system. As Klein writes:

The Falklands War in 1982 served [this] purpose for Margaret Thatcher in the UK: the disorder and nationalist excitement resulting from the war allowed her to use tremendous force to crush the striking coal miners and to launch the first privatization frenzy in a Western democracy (Klein, 2007, p. 12).

In Australia the manufactured crisis was not as dramatic as a coup or a war. However, the engineering of the Australian population's anxieties and fears around race and immigration, which was a crucial factor in the election of the Coalition in 1996, and which were embodied in asylum seekers, served the same purpose for the eleven years the Coalition was in office. This reached its high point in the worries generated during what has become known as the Tampa affair in 2001. Very briefly, the Norwegian cargo ship MV Tampa, picked up 439 asylum seekers from an unseaworthy boat and attempted to land them on Christmas Island. The Howard government refused permission and used the navy to ensure that the disembarkation did not take place. The asylum seekers were finally taken to Nauru on the HMAS Manoora (See Marr and Wilkinson, [2003] for detailed discussion of the Tampa affair). This also marked the start of the Pacific Solution. At the time of the Tampa affair the Coalition was trailing in the polls. The ALP had won state elections in Tasmania (1998), New South Wales (1999), Victoria (1999), Queensland (2001) and Western Australia (2001). In August of 2001, at the same time as the Tampa affair was unfolding, the ALP won power for the first time in the Northern Territory. Nevertheless, in the November federal election, capitalising on the fears generated by the Tampa affair and the September terrorist attacks in the United States, the Coalition retained power. This was in spite of the great unpopularity of the Coalition's neoliberal economic reforms, the centrepiece of which, the Workplace Relations Act, which 
introduced individual Australian Workplace Agreements and stripped workers of numerous rights, had been made law in 1996.

By 2007 the decline in the always small numbers of asylum seekers arriving in Australia had made any further use of this manufactured crisis unfeasible. The Howard government attempted to construct another crisis out of concerns about child sexual abuse in Indigenous communities in the Northern Territory. To this end the government created The Northern Territory National Emergency Response. Like the Tampa affair and Operation Relex, the Response also included a military aspect, the deployment of members of the army's Norforce unit under the name Operation Outreach. However, Indigenous issues do not trigger the same fears among the Australian population as do the combination of race and migration. The Coalition lost the 2007 federal election. A key contributing factor was the government's revision of the 1996 Workplace Relations Act, the Workplace Relations Amendment Act 2005, named Workchoices by the government. This radicalised industrial relations in Australia in favour of employers.

I want to comment here, briefly, on the increased use of the military in Australia, as in other neoliberal regimes, for purposes that would previously have come within the jurisdiction of the juridico-legal order and, therefore, be carried out by non-military personnel such as the police. David Harvey comments on the neoconservative social theory which has operated in conjunction with neoliberalism. He writes that: 'The anarchy of the market, of competition, and of unbridled individualism ... generates a situation that becomes increasingly ungovernable. It may even lead to a condition verging on social anarchy and nihilism' (Harvey, 2007, p. 82). Harvey goes on to argue that:

The neoconservatives therefore emphasize militarization as an antidote to the chaos of individual interests. For this reason, they are far more likely to highlight threats, real or imagined, both at home and abroad, to the integrity and stability of the nation (Harvey, 2007, p. 82). 
These threats will require the involvement of the military. Here we can see how the neoconservative theory of society connects with the neoliberal construction of crisis to reinforce the apparent need for the use of the military at the border or, indeed, at other sites of apparent social crisis within the nation-state. In Australia this has meant the involvement of the military in the 'protection' of the border and, subsequently, in the 'protection’ of Indigenous Australia.

Where a police force functions to enforce the state's laws, the role of the military is to defend the state. The increased use of the military at the border, and within the state, functions as a marker in the shift towards greater authoritarianism - an authoritarianism characteristic of the ordering of the state as described by the English seventeenth-century political theorist Thomas Hobbes, about whom I shall have much to say later. Here, I shall simply refer to Louis Althusser who, in his celebrated essay, 'Ideology and Ideological State Apparatuses', writes of the army that, within the state, it 'intervenes directly as a supplementary repressive force in the last instance, when the police and its specialized auxiliary corps are “outrun by events”, (Althusser, 1971). The use of

the military signals a decrease in the acceptance of the rule of law and narrows the role of the juridico-legal order, placing more responsibility for social order in the hands of the political system. In Australia, while the Constitution invests the Governor-General as Commander-in-Chief, there has been a push since the 1970s, not coincidentally the period when neoliberal ideology was taking root in Australian politics, for the control of the armed forces to lie with the Executive (Steven, 1983). The kind of crises identified by Klein invariably involves the use of the military.

\section{What Is the Australian Border?}

The changing concerns over migration have transformed the understanding of the border. Catherine Dauvergne (2008, p. 119) writes that, 'citizenship law and migration law work together in creating the border of the nation'. She argues that 'migration law is being transformed into the last bastion of sovereignty' (p. 169). Her reasoning is that, 'as the capacity for national 
governments to influence policy in many areas is eroded by global forces, control efforts have been concentrated on those areas that remain, ostensibly, within the direct control of national lawmakers' (p. 169). While this is partially correct what we will find is that, for a number of further reasons, the border is of central importance to the functioning of the neoliberal state. Indeed, not only does the idea of the border occupy a crucial place in all Australian discussions of migration and the regulation of migration, it is something that has been especially important in the mythic understanding of asylum seekers. What I will argue is that the role of the border has been transformed through the instauration of neoliberal policies. This is the case globally but my interest here is specifically with Australia.

Angela Mitropoulos has reworked an argument of Althusser's to highlight the importance of the border to the establishment of capitalism. In 'The Underground Current of the Materialism of the Encounter', Althusser notes that what he calls the encounter between raw labour-power and the owners of money 'occurred several times in history before taking hold in the West' (Althusser, 2007, p.197. Althusser's italics). He goes on to argue that what was necessary for the take-off of capitalism was 'a domestic market capable of absorbing what might have been produced' (p.197. Althusser's italics). What enables such a domestic market, Althusser notes, was the nation-state. However, Althusser suggests that one other element crucial to capitalism's take-off was 'an accumulation of producers (proletarians divested of all means of production)' (p. 198). As Mitropoulos (2006a) remarks in her commentary on this section, Althusser is arguing that the nation-state founds not only 'the formation of a domestic market in goods...but a domestic market in labour'. In economic terms, then, we can say that the border brings order to capitalism. However, the border's relation to order is much broader than this. As Prem Kumar Rajaram and Carl Grundy-Warr argue:

The border ... is a transformative and creative instrument; it marks the transition from a state of anarchy to one of order, thus enabling a narrative of justice and recognition centering on the clarification of what 
form of life or living constitutes belonging and what constitutes nonbelonging' (Rajaram and Grundy-Warr, 2007, p. xii).

The opposition of order and disorder, distinguished by the border and centred on the limitation of the movement of people, has been crucial to the organisation of capitalism in the modern state.

In a discussion of Giorgio Agamben's idea of the state of exception, Dominick LaCapra writes:

In the runaway state of exception (which seems close to Schmitt's state of emergency), the exception becomes the rule (hence the distinction becomes blurred or breaks down), and pre-existing normative and legal orders are suspended. (At the limit one is in a 'state' of anomic or Hobbesian war.) Agamben sees this condition as generalized or rampant in the post-Auschwitz world, and this allows him to assert that the camp is the prototype of modern life and that Auschwitz is now everywhere (LaCapra, 2007).

In this dense passage, one of the things that LaCapra is explicating is Agamben's history of the state of exception as an institutional practice. The state of exception is founded in the idea of the nation-state. As Agamben (2005, p. 4) himself writes: 'The state of exception is not a special kind of law (like the law of war); rather, insofar as it is a suspension of the juridical order itself, it defines law's threshold to the limit concept'. For Agamben the limit case of the state of exception is the Nazi regime (p. 38). The concentration camp is the product and manifestation of that state.

Agamben argues that the state of exception is always already implicit in the idea of the nation-state. In Homo Sacer, Agamben thinks about the relationship between that state of nature and sovereignty:

It is important to note that in Hobbes the state of nature survives in the person of the sovereign, who is the only one to preserve its natural ius contra omnes. Sovereignty thus presents itself as an incorporation of the state of nature in society, or, if one prefers, as a state of indistinction between nature and culture, between violence and law, and this very 
indistinction constitutes specific sovereign violence’ (Agamben, 1998, p.

35).

Sovereignty incorporates the exception. At the same time, the state in the rule of law is marked out from the exception-the state of exception is always present as a possibility implicit in the state ordered by law. We can extrapolate from this that the more sovereignty expresses that violence, for example in its use of the military rather than the police, the further it moves from the rule of law and the nearer it comes to the state of exception.

Agamben links the exception to the state of nature: 'Far from being a prejudicial condition that is indifferent to the law of the city, the Hobbesian state of nature is the exception and the threshold that constitutes and dwells within it' (Agamben, 1998, p. 106). Here, the threshold, the border, distinguishes the state of exception from the state of norms, indeed of the rule of law, which is the normative nation-state. As Rajaram and Grundy-Warr write:

Agamben understands the border as a concept distinguishing norm from exception. This exception is cast out from the norm, but in the act of casting out, the exception is brought into the system of the nation-state' (Rajaram and Grundy-Warr, 2007, p. xix).

Metaphorically, then, the border marks the distinction between the order of the practice of the nation-state and the disorder of the state of exception that lies beyond it-and yet is always already implicit within it.

Agamben's image of the state of nature, which as a political fiction had a lengthy history, is specifically that of Thomas Hobbes as detailed in Leviathan (1651) and other works. For Hobbes the state of nature is indeed, as Agamben writes, the war of all against all. It is a circumstance where, as Hobbes lists, there is nothing that obtains in the ordered state including 'no place for industry', that is no work. For Hobbes, the state, brought about through the social contract, is the way that naturally aggressive and competitive human beings are ordered and disciplined. In The Political Theory of Possessive Individualism, C.B. Macpherson argued that what Hobbes understood as natural to humans were 
learnt characteristics necessary to the practice of a market-based economic order. Macpherson (1962, p. 22) explains that: 'To get to the state of nature, Hobbes has set aside law, but not the socially acquired behaviour and desires of men'. We should note here that, as Macpherson indicates, law is the foundational ordering feature of the state. Writing that:

If a single criterion of the possessive market society is wanted it is that man's labour is a commodity, i.e., that a man's energies are his own yet are regarded not as integral parts of his personality, but as possessions, the use and disposal of which he is free to hand over to others for a price (Macpherson 1962, p. 48).

Macpherson explains that only in such a society 'in which each man's capacity to labour is his own property, is alienable, and is a market commodity, could all individuals be in this continual competitive power relationship' (p. 59). There is a lot of freight, then, in Agamben's use of Hobbes' state of nature. It would seem that one way we can identify Agamben's state of exception is as the dark side of capitalism, the world of the unfettered market beyond the border of the legally ordered, regulated, capitalist state.

While the Hobbesian state of nature functions outside of the law, Agamben asserts that 'the state of exception is neither external nor internal to the juridical order' (Agamben, 2005, p. 23). His point is that a state of exception is instituted when there is 'a (total or partial) suspension of the juridical order', but that '[t]he suspension of the norm does not mean its abolition' (p. 23). Where, philosophically speaking, the state of nature exists prior to the state, the possibility of the state of exception exists as a consequence of the existence of the state. The state of exception functions through the Hobbesian idea of authoritarian, sovereign power. In Hobbes' view, such power is not limited by law. It has no limits. The state of nature and the state of exception become homologous at the moment of the collapse of sovereign power.

This leads us to a further question. LaCapra makes the point that Agamben sees the state of exception 'as generalised or rampant in the post- 
Auschwitz world'. How has this come about? In an original and weak reading of Agamben, Aihwa Ong (2006, p. 5) writes that he 'has used the exception as a fundamental principle of sovereign rule that is predicated on the division between citizens in a juridical order and citizens stripped of juridical-political protections'. At the same time she does make the important connection between the idea of exception and neoliberalism. She writes that, in contrast to Agamben, she conceptualises:

the exception more broadly, as an extraordinary departure in policy that can be deployed to include as well as exclude. As conventionally understood, the sovereign exception marks out excludable subjects who are denied protections. But the exception can also be a positive decision to include selected populations and spaces as targets of [quoting Stephen Collier] 'calculative choices and value-orientation' associated with neoliberal reform (Ong, 2006, p. 5).

In the Australian case, Ong's insight here helps us to understand the marketbased, calculative decisions to exclude apparently unskilled asylum seekers and minimise the acceptance into the country of refugees while encouraging much greater numbers of skilled migrants without reference to any moral criteria.

However, Ong's most important point involves her recognition of the relationship between neoliberalism and exception. She uses the term 'yoking' to describe how the two processes inter-relate. Ong thinks of neoliberalism in terms of two sets of 'optimizing technologies' (p. 5). One of these is technologies of subjection which, she writes, 'inform political strategies that differently regulate populations for optimal productivity, increasingly through spatial practices that engage market forces' (p. 6). This, again, is something that we can see in the differentially graded access to rights and entitlements of the various Australian visa groups, a grading which is directly related to the labour needs of the Australian economy.

For Ong, exception is a way of understanding the political intervention in the juridico-legal order as a means of 'optimizing' that market practice of the economy which is a key characteristic of neoliberalism. The question here is, 
why was the optimization increasingly thought to be necessary? During the 1970s, the established organization of capitalism was unsettled. Along with this, as we shall see, the form of the migration structure, including the practices of the border, were transformed. In the post-Second World War period John Maynard Keynes' ideas for a state-managed capitalism, a way of avoiding another capitalist crisis like the Great Depression of the 1930s, had become generally accepted to a greater or lesser extent. The Keynesian state kept a clear division between the roles of the political, the juridico-legal and the economic. The political order managed the state as a distinct and bounded entity. David Goldberg (2009, p. 384) has usefully described this formation as the container state. He explains that it froze space. However, the 1970s and 1980s saw a transformation in the form of capitalism. Al Campbell (2005, p.188) asks, 'why productive capital subscribed to Keynesian ideas after WWII and then came to abandon nearly all of them by the 1970s and 1980s'. His answer is that:

Broadly, there was a structural crisis of capitalism. That is, the policies, practices and institutions that had been serving well capitalism's goal of capital accumulation ceased to do so. More narrowly, one can say that capitalism abandoned the Keynesian compromise in the face of a falling rate of profit, under the belief that neoliberalism could improve its profit and accumulation performance (Campbell, 2005, p. 189).

As profits fell, capitalists looked for ways for reinstating their profit margins. Walter Bello (2005, p. 79) argues similarly: 'The fundamental cause of the long downturn was a crisis of profitability. It stemmed from downward pressure on prices, the result mainly of the conjunction of stagnant demand and excess industrial capacity, which in turn triggered intense competition among the center economies’. Bello goes on to explain that:

The process of neoliberal reform ... was marked by destabilising contradictions, in the North and in the South. Liberating capital from the constraints of governments that had imposed a compromise between labor and capital and a modus Vivendi between northern capital and developing elites entailed (1) bringing down wages, which meant cutting 
the engine of demand that capital needed in order to reproduce itself profitably, and (2) adding to the ranks of the global unemployed, as the penetration of goods and capital into less developed economies bankrupted local firms and farms, eliminating millions from the market (Bello, 2005, p 83).

These developments directly relate to the increase in global migration. A Global Commission on International Migration report ('Migration at a glance', 2005, p. 83) tells us that: 'Numbers are increasing rapidly: from 82 million international migrants in 1970 through 179 million in 2000 to nearly 200 million today'. In developed countries, the countries of the North, which, however, includes Australia, the border has become the neoliberal filter where decisions that have been made about the economic worth of these migrants to the nation-state are instituted.

One way of thinking about neoliberalism is that it is an ideology whose time had come. David Harvey, with his usual perception, argues that: 'We can interpret neoliberalism either as a utopian project to realize a theoretical design for the reorganization of international capitalism or as a political project to reestablish the conditions for capital accumulation and to restore the power of economic elites' (Harvey, 2007, p. 19). He remarks, though, that: 'The evidence suggests ... that when neoliberal principles clash with the need to restore or sustain elite power, then the principles are either abandoned or become so twisted as to be unrecognisable’ (p. 19). For Harvey the crisis of the 1970s was of capital accumulation. As he writes: 'The crisis of capital accumulation in the 1970s affected everyone through the combination of rising unemployment and accelerating inflation' (p. 14). Neoliberal policies appeared to offer elites a solution to the economic woes of capitalism while enabling them to re-establish their profit margins.

This neoliberal reworking of capitalism provides us with a way of thinking about the generalisation of the state of exception in the post-Auschwitz world. One key characteristic of the neoliberal state is the decline in the power of the law. Increasingly, the juridico-legal order of the state is bypassed in favour of 
politically motivated decision-making. This is typically the case in the processes that surround migration and, as we shall see, is very much in evidence in relation to the management of the Australian border. While neoliberalism is clearly not a necessary condition for the state of exception, the state of exception is the ideal type of the neoliberal state; that is the state whose purpose is to optimise the capitalist market at the expense of moral criteria, and legal processes, in favour of profit and capital accumulation.

The neoliberal state grades the population, as labour, in order to optimise the needs of the market. For Goldberg this is the traffic cop state. This 'order[s] flows[,] freezes time and controls through special regulation, through normalized exception' (Goldberg, 2009, p. 348). One of the most important flows, as we have begun to see in the case of Australia, is people. However, whereas in the traditional container state a person was, in the first place, either inside the state or outside, now membership of the state, and therefore one's relationship to the border, is graduated. This means that the status of the border changes. It becomes a national site dominated by economic determinations. On the one hand it becomes more impermeable. Those who are of no use to the socio-economic system of the state are to be excluded at all cost - and we have already seen how expensive it has been to operate the detention centres for asylum seekers attempting to enter Australia. On the other hand the border gains porosity, allowing in and out those who have skills that the socio-economic system requires, and then no longer requires.

Markus Euskirchen, Henrik Lebuhn and Gene Ray have discussed the transformation of the European border regime. They note how Europe has come to be identified as 'Fortress Europe' and how, indeed: 'High walls are being built around the wealthy cores of the Global North to keep out millions of people who are forced to leave their home countries in order to survive' (Euskirchen et al., 2007). In an interview with Peter Mares in 2000 when Mares asked about the possibility of quarantining the 12,000 places the government had set aside for refugees from places given to asylum seekers awarded refugee status, Ruddock bridled. His response was to ask if Mares thought Australia should take the 21 
million refugees that the Office of the United Nations High Commissioner for Refugees estimated were in the world at that time (Mares, 2001, p. 111). It is clear that Ruddock is thinking of a Fortress Australia with a border functioning like that of Europe. It should be pointed out that this anxiety over migrants to the rich, white core is nothing new. In 1974 Charles Price published a book titled The Great White Walls Are Built in which he discussed the historical process through the nineteenth century of putting in place a restrictive and racialised immigration program across North America and Australia. I will return to the matter of race shortly.

At the same time, Euskirchen et al. (2007) also remark on the European border's 'ability to differentiate and regulate'. Referring to work by Tobias Pieper they explain that the border regime distinguishes four groups of people according to their economic worth for Europe:

(1) highly qualified workers from the capitalist periphery who are actually recruited or invited to work in Europe; (2) low-skilled guest workers who legally come to Europe, mainly to Germany, on short-term visas to live and work under very restricted conditions; (3) an illegalized trans-national labor force of workers who lack any former rights or protections for the negotiation of their living and working conditions, and (d) economically superfluous refugees, who increasingly are denied any secure legal status in Europe (Euskirchen et al., 2007).

As in Australia, this is not only a gradation of entry, it is also a gradation of rights and entitlements within Europe; a grading of legal presence according to economic criteria governed by political decisions.

Euskirchen, Lebuhn and Ray remark that: 'In effect, the old lines of national demarcation are being transformed into new and militarized border zones and spaces that overlay the social space of everyday life. Europe is becoming a borderland' (Euskirchen et al. 2007). For these writers this development is happening as the new European border of the European Union takes over the role of individual nation-state borders. As in Australia, this new border is militarised, marking a shift of control from the juridico-legal order to the political order, and 
the border expands to become increasingly synonymous with the land it bordersin Australia with the nation-state itself. This occurs as a steadily increasing percentage of people resident within the state are not citizens. If we think about this development in terms of Agamben's state of exception we can appreciate how, as the traditional capitalist state is transformed by degrees into the neoliberal state of exception, so the border, which is the materialised hinge between the state forms, becomes the site for the most dramatic enactment of the state of exception. In Australia this is most apparent in the establishment of the regime of detention centres. Suvendrini Perera has discussed these as spaces of exception in the context of Agamben's work and a genealogy of the camp in settler Australian history. She refers to the detention centre as: 'A place that is ... not Australia' because of its excision from the Australian juridico-legal system (Perera, 2002).

\section{Racing the State-and the State of Exception}

At this point we need to start thinking about the centrality of race to the articulation of the modern state. Goldberg argues that:

Race appears in this scheme of things [the organisation of the modern state] as a mode of crisis management and containment, as a mode mediating that tension, of managing manufactured threats and of curtailing while alienating the challenge of the unknown. As a representative of the Natural Order (the State of Nature in Hobbes, Pufendorf, Locke, Rousseau), race stands for that which the modern state is not, what the state avoids, what it is to keep at bay. Notwithstanding the differences between them, it is instructive that the principal or only examples these social contractarians respectively cite for the State of Nature are deeply configured in racist terms. ... (Goldberg, 2002, p. 40).

The state and its mythic Other, the state of nature, are fundamentally raced. Writing specifically about Hobbes, Goldberg asserts that he 'render[s] explicit a rationalizing narrative concerning the modern state legitimation, one central to which are the configurations of gendered and raced domination intertwined with and expressed in and through class' (p. 41). To this we can add Mitropoulos' observation that, 'the distinction between frontier spaces and bordered realms 
correlates with the distinction - in Social Contract theories-between the 'state of nature' and 'society' that, in turn, are the ideological placeholders for the 'West' and the colonies' (Mitropoulos, 2003, p. 374). If the state of nature is a version of Agamben's state of exception then that, too, is racially marked.

If the modern state is raced from its European origins then its reworking as the neoliberal state is also raced. More, if the neoliberal state marks the instantiation of the state of exception in state form, then that state is doubly raced. In practice this means that where the European state was marked by the exclusion of those identified as non-white, the state operation of capitalism was a white preserve, in the neoliberal state those that were racially excluded are allowed to enter on the rational, calculative terms of the market. Where with the modern state racial segmentation mapped onto economic segmentation, in the neoliberal state both forms of segmentation are imbricated as its ordering mechanism while the actual presence of the racial Other continues to be strictly controlled.

At this point I want to set in place another piece of this puzzle. Earlier, following Althusser, Mitropoulos and Goldberg, I argued that the modern state was central to the elaboration of capitalism because its borders contained those who then had no option but to supply their labour-power to those who, using a Marxian term, owned the means of production. However, as we have seen, borders also function to regulate entry to the state. Mitropoulos argues that, 'without the foreigner, the nation and practice of the social (or wage) contractas a voluntary agreement between more or less symmetrical agents-falls apart' (Mitropoulos, 2006b). The foreigner is the excluded Other, both philosophically and racially, whose exclusion enables the contract to be fixed. It has been a requirement of the modern state that entry was regulated. John C. Torpey argues that 'modern states, and the state system of which they are a part, have expropriated from individuals and private entities the legitimate "means of movement," particularly though by no means exclusively across international boundaries' (Torpey, 2000, p. 4). As the nation-state became more organised so the role of the border became ever more important: 
As markets for labor power, in particular, became "nationalized," states asserted dominion over the right to determine who could move about and under what conditions. The general result of the process was that local borders were replaced by national ones, and that the chief difficulty associated with human movement was entry into, not departure from, territorial spaces (Torpey, 2000. p. 20).

By the early years of the twentieth century countries had begun to impose migration restrictions and, during World War One, passports started to be generally needed for crossing national borders.

As a modern state, Australia's exceptionalism at the time of federation in 1901 lay only in its overt assertion that it was to be a white nation-state and that this would be the over-riding imperative of its immigration policy. As Marilyn Lake and Henry Reynolds write (2008, p. 152): 'In the Commonwealth of Australia, white men appropriated the discourse on civilisation for themselves, defining it in terms of wages and conditions and the standard of living'. Lake and Reynolds go on to quote Alfred Deakin, the leader of the push for federation and Australia's second prime minister. Deakin, they write:

explicitly theorised White Australia as an exercise in social justice: 'it means the maintenance of conditions of life for white men and women; it means equal laws and opportunity for all; it means protection against the underpaid labor of other lands; it means social justice so far as we can establish it, including just trading and the payment of fair wages (Lake \& Reynolds. 2008. p. 153, 154).

Whiteness was overtly central to Australian capitalism and a founding feature of the Australian state until the ending of the White Australia policy in the early 1970s.

Referring to the large increase in migration numbers in the decades after the Second World War, which I have mentioned earlier as caused by the desire to establish an industrial base in Australia, Stephen Castles and Ellie Vasta write that: 
From the 1860s to the 1960s unions largely supported the White Australia Policy. After World War II, the unions only accepted the migration program after receiving assurances that the migrants would not take jobs from Australian workers (Castles and Vasta, c1994, p. 159).

During this post-Second World War period the official Australian understanding of whiteness was expanded to include people from Mediterranean and Eastern European countries.

Nevertheless, as Castles and Mark Miller write:

Up to about 1973, ... Australian ... immigration policies were concerned with the recruitment of a manual labour force. Non-British migrants who received assisted passage to Australia were directed into jobs on construction sites such as the Snowy Mountain Hydro-electric Scheme, in heavy industry or in factories (Castles and Miller, 1998, p. 193).

As we have seen, the 1970s saw the end of the Keynesian compact. Before this, Australia, like most core, white states, required the migration of people for manual labour. Most of these migrants were identified as non-white. In Britain, for example, labour was drawn from the West Indies and from South Asia. Germany took in guest-workers from Turkey. In Australia, while the Italian, Greek, Lebanese and other migrants were officially classified as white they remained discriminated against in everyday life.

While white, British migrants were also often employed as unskilled labour they found it easier to get better paid jobs and climb the social order. To quote Castles and Miller again:

Economic restructuring since the 1970s has brought significant changes. In [Australia] the pre-1973 entrants bore the brunt of the restructuring, as low-skilled jobs in manufacturing declined. Research in Australia has shown that unemployment during the recessions of 1974-5, 1982-3 and 1990-2 was significantly higher for non-English-speaking background immigrants than for other workers (Castles and Miller, 1998, p. 195). 
In the traditional state, when non-white migrants were allowed in in any numbers they were channelled into low-level manual labour jobs. In Australia, this is what happened to the newly reclassified 'white' migrants in the post-Second World War period. While formally identified as white, in the main they took manual labour jobs and found themselves able to rise in the economic order to only a limited extent. In other words, in spite of official claims to the contrary, these migrants were treated as non-white.

Through the 1970s, Australia instituted multiculturalism as a population management policy. I have discussed this elsewhere (Stratton, 1998). The official aim of multiculturalism was to help migrants from diverse cultural and linguistic backgrounds to settle in Australia by acknowledging and valuing their cultural differences. In practice, as numerous critics have pointed out, multiculturalism functioned as a core and periphery structure where the members of the Anglo-Celtic core remained in positions of power while the relatively powerless ethnic minorities were meant to take solace in the new valuation of their cultural practices. In economic terms this was a re-emphasising of a middle class and working class structure. In other words through the decades after the Second World War Australia established a racialised class structure founded in the economic order and disguised while reinforced by multiculturalism.

When globalisation forced a restructuring of the Australian economy in the last quarter of the twentieth century, as Castles and Miller (1998) explain, a disproportionate number of this racialised — for which in Australian multicultural terminology read 'ethnicised' because they were officially thought of as whiteworking class were made unemployed. However, they had migrated to Australia on a permanent basis and many had citizenship. ${ }^{1}$ Thus, they became the responsibility of the state. In the neoliberal Australian state far fewer migrants take out citizenship, indeed this is not possible on a 457 visa which enables the holder to stay for three years and is granted provided a company offers employment. These, as it happens, middle-class, skilled workers will have to return to their country of origin if an economic downturn, or another restructuring, means that their skill is no longer in demand. Analogously, in 2009 the 
government gave the go-ahead for a new guest-worker scheme to bring in 2,500 workers from the Pacific Islands on three year visas for seven months in any twelve month period to work in low-level, seasonal jobs such as fruit-picking (see Millbank, 2008; 'Fruit growers furious', 2009). Unlike the post-Second World War migrants these unskilled non-white workers will also be returned to their countries of origin when the economic need for them no longer exists.

\section{Back To the Border}

In Australia, and indeed in Europe, the anxiety over those described as asylum seekers grew as elements of the neoliberal state were beginning to be put in place. The term 'asylum seeker', we should remember, is used for people who have not, or not yet, been classified as refugees - that is, incorporated into the international legal order. 'Asylum seeker' is a placeholder. In Australia those now conventionally described as asylum seekers have been called boat people, queue jumpers, possible terrorists, and, with a certain unconscious irony, economic migrants, among other appellations. These people are thought of as illegal. Discussing the use of this term, Dauvergne (2008, p. 10) notes that: 'By the late 1960s it ['illegal'] was used in quotation marks, or as a repeat reference, once illegal immigrants had already been discussed. Now it is used without drawing any special attention at all'. It has been during the ascendency of neoliberalism that 'illegal' has become a noun to describe a category of people. Dauvergne writes that:

Although the term "illegal" is precise in its relationship with the law, it is empty of content. It says even less than other identity markers in the migration hierarchy: resident, visitor, guest worker or refugee. It circumscribes identity solely in terms of a relationship with law: those who are illegal have broken (our) law (Dauvergne, 2008, p. 16).

Those described as illegals are not named. The term functions similarly to 'asylum seekers'. These people are placed outside of the state, an empty category containing the anxieties of those who live their everyday lives in the neoliberal 
order, provoking the dread that they might cross the border and bring the anarchy, the state of nature, out there, in here, into the, in this case, Australian nation-state.

One way of thinking about these abject people is that they do not have access to the rights and entitlements, and the quality of life, of those who are allowed to live within the border of the state. For Ruddock, in his interview with Mares, the relatively few asylum seekers that have arrived on the Australian border metamorphose into the terror of Australia being overwhelmed by 21 million refugees.

The dread of the loss of distinction between an ordered 'inside' and a chaotic 'outside' became greatest as Australia was being transformed into a traffic-cop state with a partially permeable border, greatest also as the neoliberal state of exception began to supplant the traditional, juridico-legally ordered state. Without the law, as Hobbes understood, power was its own legitimation and the fear is of the loss of that ordering power. When the law is set aside, it is simply authoritarian power, manifested in military force, which marks the site of the border. After all, paradoxically, as LaCapra indicates, at the fantastic, final moment when the neoliberal state of exception is fully established there would be no border, nothing to distinguish 'inside' from 'outside'. For Agamben, a defining quality of the state of exception is that the rule of law is set aside. Once the law is gone, there is nothing to ensure its restoration. Order is defined by the whim of the sovereign and is always on the verge, the border, of chaos. It is important to remember that, for Agemben, as we have seen, 'the state of nature survives in the person of the sovereign'. And it is only this authoritarian power which stands between the fragile order of the raced state and the anarchic chaos of the racialised state of nature. Only this lawless authority stands between the state of nature and the state of exception. It is no wonder, then, that the understanding of the Australian border should have been transformed; that the fear of this neoliberal nation-state being overwhelmed by racially Othered asylum seekers should be so powerful. 


\section{Postscript}

As I was finalising this article another boatload of asylum seekers was picked up in Australian waters. This makes six boats this year to date (April 17 $7^{\text {th }}, 2009$ ) carrying a mere 264 asylum seekers. Not very many at all when compared with Australia's annual, total migration intake of around 170,000 people. Nevertheless, the national newspaper The Australian's lead headline for April $16^{\text {th }}$ was 'Rising tide of boatpeople (sic)', evoking once again the spectre of Australia(ns) being drowned under an incoming sea of seemingly threatening asylum seekers.

I thank Suvendrini Perera for her close and thoughtful reading of an earlier version of this article. I have taken up many of her suggestions. Some I have not used and it may be that the article is the worse for that. Some of the ideas in this article have been stimulated by my supervision of Kristen Phillips' fine doctoral thesis on the gendering of asylum seekers in Australia.

\section{References}

Agamben, G. (1998) Homo Sacer: Sovereign Power and Bare Life. Stanford, Calif.: Stanford University Press.

Agamben, G. (2005). State of Exception. Chicago: University of Chicago Press.

Althusser, L. (1971). Ideology and Ideological State Appartuses. In Lenin and Philosophy and Other Essays. (Ben Brewster, Trans.). London: New Left Books.

Althusser, L. (2006). The Underground Current of the Materialism of the Encounter. In Philosophy of the Encounter: Later Writings (1978-1987).

(François Matheron, Ed.) (G. M. Goshgarian, Trans. and intro.). London: Verso.

Bello, W. (2005). Dilemmas of Domination: The Unmaking of the American Empire. New York: Metropolitan Books.

Campbell, A. (2005). The Birth of Neoliberalism in the United States: A Reorganisation of Capitalism. In A. Saad-Filho and D. Johnston (Eds.), Neoliberalism: A Critical Reader, London: Pluto. 
Castles, S. and Miller, M. (1998). The Age of Migration: International Population Movements in the Modern World. Basingstoke: Macmillan.

Castles, S. and Vasta, E. (1994). Australia: New Conflicts Around Old Dilemmas. In W. Cornelius and P. Martin (Eds.). Controlling Immigration, 2nd ed., Stanford, Calif.: Stanford University Press.

Dauvergne, C. (2008). Making People Illegal: What Globalization Means for Migration and the Law. Cambridge: Cambridge University Press.

Euskirchen, M., Lebuhn, H. \& Ray G. (2007). From Borderline To Borderland: The Changing European Border Regime. In Monthly Review. Retrieved April 14, 2009, from http://www.monthlyreview.org/1107euskirchen-lebuhn-ray.htm

Fruit growers furious as seasonal workers scheme delays continue. ABC News. Retrieved Jan 31, 2009, from

http://abc.com.au/news/stories/2009/01/30/2478180.htm?section=justin

Goldberg, D.T. (2009). The Threat of Race, Reflections on Racial Neoliberalism. Malden, Mass.: Wiley-Blackwell

Goldberg, D. T. (2002). The Racial State. Malden, MA: Blackwell Publishers.

Harvey, D. (2007). A Brief History of Neoliberalism. New York: Oxford University Press.

Jordens, A-M. (1997). Alien To Citizen: Settler migrants in Australia 1945-75. St. Leonards, NSW: Allen \& Unwin.

Kelly, P. (2008). Labor promises massive increase in migration to lure workers. The Australian. Retrieved May17, 2008, from http://www.theaustralian.news.com.au/story/0,25197,23711763-601,00.html

Klein, N. (2007). The Shock Doctrine: The Rise of Disaster Capitalism. London: Allen Lane.

Klocker, N. (2008). Community antagonism towards asylum seekers in Port Augusta, South Australia. Australian Geographical Studies, 42(1).

LaCapra, D. (2007). Approaching limit events: Siting Agamben. In M. Colarco and S. DeCaroli (Eds.), Giorgio Agamben: Sovereignty and Life (pp.126-162). Stanford: Stanford University Press.

Lake, M. and Reynolds, H. (2008). Drawing the Global Colour Line. White Men's Countries and the International Challenge of Racial Equality. Carlton: Melbourne University Press. 
Macpherson, C.B. (1962). The Political Theory of Possessive Individualism: Hobbes to Locke. Oxford: Clarendon Press.

Mares, P. (2001). Borderline: Australia's Response to Refugees and Asylum Seekers in the Wake of the Tampa. Sydney: UNSW Press.

Marr, D and Wilkinson, M. (2003). Dark Victory. Crow's Nest, N.S.W.: Allen \& Unwin.

(Migration at a glance, Appendix ii). Migration in an Interconnected World: New Directions for Action, Report of the Global Commission on International Migration. (October 2005). Retrieved April 14, 2009, from www.gcim.org/attachements/gcim-complete-report-2005.pdf

Millbank, A. (2008). Guest-workers for Australia: Win-win, token gesture or moral hazard. People and Place, 16(3), pp. 58-67.

Mitropoulos, A. (2002). Notes on the Frontiers and Borders of the Postcolony. Sarai Reader 'Frontiers'. Retrieved April 14 ${ }^{\text {th }}$, 2009, from http://www.sarai.net/publications/readers/07-frontiers/372-379_angela.pdf

Mitropoulos, A. (2006a). The Encounter and the Border. Retrieved April 14, 2009, from http://archive.blogsome.com/2006/01/04/aleatory-materialism-border/

Mitropoulos, A. (2006b). Under the Beach, the Barbed Wire. In Mute: Culture and Politics After the Net. Retrieved April 14, 2009, from http://www.metamute.org/en/Under-the-Beach-the-Barbed-Wire

Ong, A. (2006). Neoliberalism as Exception, Mutations in Citizenship and Sovereignty. Durham N.C.: Duke University Press.

Paddock, R.C. (2002). Refugee sues Australia over detention fees. Los Angeles Times, 2 September 2002. Retrieved April 14, 2009, from http://articles.latimes.com/2002/sep/02/world/fg-asylum2

Perera, S. (2002). 'What is a camp...?'. borderlands, 1(1), Retrieved April 14, 2009, from http://www.borderlands.net.au/vol1no1_2002/perera_camp.html

Rajaram, P.K. and Grundy-Warr, C. (Eds.) (2007). Introduction. In Borderscapes: Hidden Geographies and Politics at Territory's Edge. Minnesota:

UniverMinnesota.

Reilly, A. (1995). Detention of asylum seekers: A questionable policy.

Multiculturalism and the Law. Canberra: Australian Institute of Criminology. 
Retrieved April 14, 2009, from

http://www.aic.gov.au/conferences/multiculturalism/reilly.pdf

Steven, Sir. N. (1983). Address by His Excellency the Right Honourable Sir Ninian Stephen Governor-General of the Commonwealth of Australia on the occasion of the Graduation of Course no. 27/83 of the Joint Services Staff College, Canberra on Tuesday, 21 June 1983. Retrieved April 14, 2009, from http://www.gg.gov.au/governorgeneral/content.php?id=16\#_ftn1

Stratton, J. (1998). Race Daze: Australia in Identity Crisis. Sydney: Pluto Press.

Torpey, J.C. (2000). The Invention of the Passport: Surveillance, Citizenship and the State. Cambridge [England]; New York: Cambridge University Press.

Vernon, K. (2008). Labor retains mandatory detention of refugees. Direct Action. Retrieved April 14, 2009, from

http://directaction.org.au/issue4/labor_retains_mandatory_detention_of_refugees

1 There was considerable reluctance among European migrants to Australia in the post-Second World War period to apply for citizenship-a status which only acquired a legal existence after the passing of the Nationality and Citizenship Act in 1948, which came into force on Australia Day, 1949. Ann-Mari Jordens writes that: 'In 1956 the Department [of Immigration] calculated that only 77,670 (35.2\%) of the 220,380 aliens who were registered in June 1951 had applied to become citizens.' (p. 180.) 